\title{
GLIFY MAJÓW JAKO NAJBARDZIEJ ROZWINIECTY SYSTEM PISMA W MEZOAMERYCE
}

\author{
BOGUCHWAŁA TUSZYŃSKA
}

\begin{abstract}
One of the major achievements of the Maya civilization was an introduction and development of an exceptionally refined writing system. In the history of that civilization, three basic periods may be distinguished: pre-classical (2000 yBP $-250 \mathrm{yBP})$, classical $(250 \mathrm{yBP}-900 \mathrm{yP})$, and post-classical (900 yP till the Spanish Conquest). It is especially the classical period in which a tremendous development of Maya architecture and art took place. It is also in this period that a growing number of inscriptions were produced, though the first glyphs had occurred much earlier.
\end{abstract}

Key words: Maya civilization, Maya writing system, Maya manuscripts, Maya glyphs

\section{Wprowadzenie}

Jednym z największych osiągnięć cywilizacji Majów był wyjątkowo rozwinięty i wyrafinowany system pisma. Majowie zamieszkiwali obszar należący obecnie do pięciu stanów Meksyku (Tabasco, Chiapas, Campeche, Jukatan i Quintana Roo), Gwatemali, Belize oraz zachodnich krańców Hondurasu i Salwadoru (Rys. nr 1). W dziejach tej cywilizacji wyróżniamy trzy podstawowe okresy: preklasyczny $(2000 \mathrm{r}$. p.n.e. -250 r. n.e.), klasyczny (250-900 n.e.) i postklasyczny (od 900 r. n.e. do konkwisty hiszpańskiej). Pierwsze miasta Majów, z budowlami rezydencjalnymi i świątyniami wznoszonymi na kamiennych platformach, powstawały już kilkaset lat przed naszą erą, jednak to dopiero okres klasyczny charakteryzował się ogromnym rozwojem architektury i sztuki. Ziemie Majów były wówczas podzielone na dziesiątki królestw, zarządzanych przez „boskich władców” zwanych k’uhul ajaw, z których 


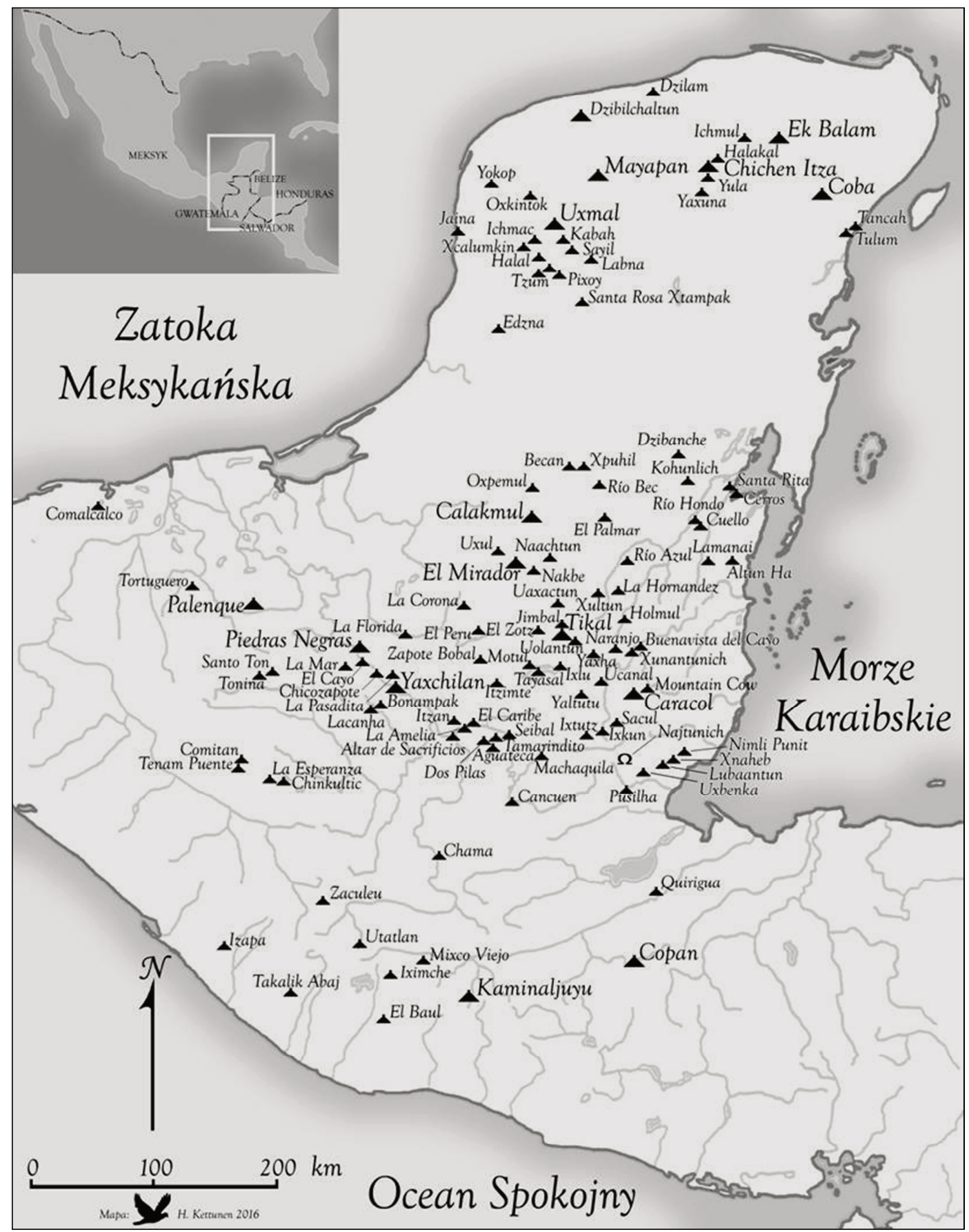

Rys. nr 1. Mapa ziem Majów pokazująca najważniejsze stanowiska archeologiczne (autor rysunku: Harri Kettunen; mapka zamieszczona dzięki uprzejmości autora) 
jedni pozostawali we wzajemnych przyjaznych relacjach, a inni rywalizowali, starając się zwiększyć strefy swych wpływów. Rozkwit cywilizacji Majów w tym okresie znalazł swój wyraz również w rosnącej liczbie inskrypcji, chociaż pierwsze glify pojawiły się znacznie wcześniej,

Najstarsza ze znanych jak dotąd inskrypcji Majów pochodzi z San Bartolo (Gwatemala), gdzie została namalowana na ścianie Budowli 1 w Grupie Las Pinturas, w późnym okresie preklasycznym, około III w. p.n.e. (Saturno et al., 2006). Stosunkowo dawne, pochodzące z II w. n.e., teksty Majów zachowały się też na drobnych przedmiotach, zwłaszcza z jadeitu, choć mogą być datowane jedynie na podstawie stylu i ikonografii. Złotym wiekiem pisma Majów okazał się niewątpliwie okres klasyczny, którego ramy czasowe zostały określone w oparciu o pierwszą i ostatnią inskrypcję z podanymi dokładnymi datami, które możemy skorelować z naszym kalendarzem i które przypadały, odpowiednio, w 292 r. n.e. i w 909 r. n.e. Teksty Majów pojawiały się też później, szczególnie malowane na stronach manuskryptów, zwanych kodeksami, które powstawały co najmniej do XVII wieku, kiedy to ostatnie miasto Majów, Tayasal (Gwatemala) poddało się władzy Hiszpanów.

\section{Prace nad odczytaniem pisma Majów}

We wczesnym okresie kolonialnym, liczni kronikarze wspominali w swych relacjach o istnieniu majańskich manuskryptów, spisanych dziwnymi znakami, ale nie starali się zgłębić tajników owego pisma, traktując je raczej jako ciekawostkę. Jedyną osobą, która wykazała większe zainteresowanie był biskup Diego de Landa, który w swej Relación de las cosas de Yucatán zamieścił nie tylko rysunki i nazwy glifów związanych z kalendarzem Majów, ale również 27 glifów, uważanych przez niego za litery alfabetu. Fragmenty zachowanej kopii tego dzieła zostały opublikowane w 1864 roku przez francuskiego kleryka Brasseura de Bourbourg. Wówczas, dzięki pierwszym rysunkom inskrypcji glificznych, które zostały wydane już wcześniej, w 1810 roku w dziele Aleksandra von Humboldta, w 1822 roku w relacji Antonia del Río oraz w książkach Johna Lloyda Stephensa i Fryderyka Catherwooda, podróżników przemierzających ziemie Majów w latach 1839-42, badacze zwrócili uwagę na pismo Majów.

W pracach nad odczytaniem inskrypcji brało udział wiele osób z całego świata, w tym zarówno naukowców, jak i amatorów zafascynowanych glifami (zob. np. Coe, 1992; Kettunen i Helmke, 2011: 8-12). Początkowo skupiono się na poznawaniu zasad funkcjonowania kalendarzy Majów, gdzie ogromne zasługi odniósł przede wszystkim Ernst Förstemann, a prace kontynuowali: Joseph T. Goodman, Juan Martínez Hernández, Sylvanus G. Morley i John Eric Thompson. Dzięki ich badaniom zrozumiano stosowane przez Majów połączenie rytualnego cyklu tzolk'in (obejmującego 260 dni, będących następującymi po sobie kombinacjami 20 dni i liczb 
od 1 do 13) ze „Zwykłym” kalendarzem haab (liczącym 365 dni, na który składało się 18 ,miesięcy” po 20 dni i 5 dni dodatkowych, kończących rok), zapis tak zwanej „długiej rachuby” (podającej liczbę dni, które upłynęły od daty bazowej związanej z wydarzeniami mitycznymi i przypadającej w dniu 13 sierpnia 3114 r. p.n.e.), a także zdołano skorelować daty Majów z datami kalendarza gregoriańskiego.

Pomimo, iż już na przełomie XIX i XX wieku, dzięki rysunkom i fotografiom wykonanym przez Alfreda P. Maudslaya i Teoberta Malera, dysponowano większą liczbą inskrypcji, to jednak nadal nie wiedziano o czym opowiadały teksty Majów. W pierwszej fazie badań wydawało się bowiem, że tak zwany „alfabet” biskupa Diega de Landa jest bezużyteczny, gdyż w rzeczywistości istniało znacznie więcej znaków. Problem polegał na tym, że sam biskup nigdy nie zrozumiał pisma Majów i był przekonany, że jego miejscowi informatorzy dyktowali mu litery alfabetu. Uczeni nie zwrócili wówczas uwagi na sugestie Cyrusa Thomasa, że glify te mogły być ideogramami i znakami fonetyczno-sylabicznymi. Przełom nastąpił w połowie XX wieku, kiedy Rosjanin Yurij Knorozow, z wykształcenia etnolog i znawca hieroglifów egipskich oraz pisma chińskiego i japońskiego, uznał, że glify przedstawione w dziele Diega de Landa były sylabami. Wychodząc z tego założenia, zdołał odczytać niektóre glify podane w majańskich manuskryptach. Jego sposób myślenia nie został od razu zaakceptowany przez świat nauki, choć wzbudził zainteresowanie takich badaczy jak David Kelley i Michael D. Coe.

Wkrótce dalsze prace wykazały, że teksty Majów opowiadają o wydarzeniach historycznych. Heinrich Berlin zwrócił uwagę na tak zwane glify-emblematy, bloki glificzne, których główny element zmieniał się w zależności od królestwa i tym samym mógł odnosić się do jego oryginalnej nazwy. Z kolei, Tatiana Proskouriakoff przeprowadziła analizę strukturalną inskrypcji z Piedras Negras (Gwatemala) i wykazała, że poszczególne daty, podane w tekstach glificznych odnoszą się do wydarzeń z życia władców, co pozwoliło na parafrazowanie tekstów i podjęcie prób ustalenia list dynastycznych w wybranych ośrodkach Majów. Jednocześnie stało się jasne, że sceny ukazane na zabytkach Majów przedstawiają postacie historyczne, a nie bóstwa lub szamanów, jak sądzono przez wiele lat. I tak w drugiej połowie XX wieku nastąpił ogromny rozwój prac nad odczytaniem glifów, który znalazł wyraz w licznych publikacjach i konferencjach, pozwalających na wymianę poglądów. Do osób, które szczególnie wyróżniły się w badaniach epigraficznych, poza wcześniej już wspominanymi, należeli: Floyd Lounsbury, Linda Schele, Peter Mathews, David Stuart, Nikolai Grube, Barbara Macleod, Stephen Houston, Alfonso Lacadena, Marc Zender czy Simon Martin.

Przed rozpoczęciem odczytywania inskrypcji, należało przede wszystkim ustalić, w jakim języku zostały one spisane. Na ziemiach zamieszkiwanych obecnie przez potomków Majów nadal istnieje około 30 języków majańskich, którymi posługuje się niemal sześć milionów osób. W tej rodzinie językowej, która wywodzi się z języka proto-majańskiego wyróżnia się pięć grup: języki huasteckie, jukatec- 
kie, ch'olskie-tzeltalskie, q'anjobalskie i wschodnie języki z Wyżyn Gwatemali (Campbell i Kaufman, 1985: 187-198). Ostatecznie uczeni postanowili nazwać język inskrypcji klasycznym ch'olti' lub po prostu językiem majańskim klasycznym (Houston et al., 2000: 322). W tekstach glificznych zidentyfikowano kilka języków majańskich, w tym przede wszystkim ch'olskie zarówno ze wschodniej gałęzi (związane ze współczesnymi ch'olti' i ch'orti'), jak i z zachodniej (związane z dzisiejszymi chontal i ch'ol), a także tzeltalskie (obecne tzeltal i tzotzil) i jukateckie (związane ze współczesnymi jukateckim, lakandońskim, itzaj i mop) (Lacadena, 2013: 5).

Języki majańskie są językami ergatywno-absolutywnymi, gdzie ergatywy służą do oznaczenia podmiotu w zdaniach przechodnich i pełnią funkcję zaimków dzierżawczych, a absolutywy określają podmioty w zdaniach nieprzechodnich i dopełnienia $\mathrm{w}$ zdaniach przechodnich. Dla trzeciej osoby liczby pojedynczej absolutyw jest morfemem zerowym i dlatego nie jest widoczny w inskrypcjach. W językach Majów występują strony: czynna, bierna, mediopasywna i antypasywna. Składnia jest odmienna niż w języku polskim, gdyż najpierw pojawia się orzeczenie (z dopełnieniem w przypadku czasowników przechodnich), a potem podmiot. Jeśli inskrypcja zawiera daty, to zazwyczaj podawane są one na początku zdań. W języku majańskim klasycznym występuje 5 samogłosek (a, e, i, o, u) oraz 21 spółgłosek (b, ch, ch', h, j, k, k', l, m, n, p, p', s, t, t', tz, tz', w, x, y, oraz znak zwarcia krtaniowego).

Język majański klasyczny współistniał z językami, którymi posługiwano się w poszczególnych regionach i był używany w inskrypcjach niezależnie od lingwistycznej przynależności skrybów i rzeźbiarzy. $Z$ tego powodu w tekstach Majów można niekiedy dostrzec wpływy regionalne (Lacadena i Wichmann, 2002: 281-282). Język majański klasyczny był językiem prestiżowym i to jedynie osoby z elity potrafiły odczytywać inskrypcje. Być może ludzie o niższym statusie społecznym byli w stanie rozpoznawać niektóre glify, na przykład podające daty lub toponimy, choć nie zawsze wydawałoby się to łatwe ze względu na wielką różnorodność glifów i ich wzajemne kombinacje, które charakteryzują system pisma Majów.

\section{Cechy pisma glificznego Majów}

Pismo Majów obejmuje około tysiąca różnych znaków, choć część z nich stanowiła jedynie warianty poszczególnych glifów bądź pojawiała się tylko w pewnych okresach lub w danym regionie. Przyjmuje się zatem, że w tym samym czasie używano maksymalnie około 500 glifów (Kettunen i Helmke, 2011: 8).

Inskrypcje Majów zapisywane były w blokach, których kolejność odczytu została ustalona przez Cyrusa Thomasa już pod koniec XIX wieku, gdyż wystarczyła 
do tego znajomość glifów związanych z kalendarzem, które pojawiają się zawsze w ściśle określonej i znanej już wówczas sekwencji. Poszczególne bloki glificzne odczytujemy zazwyczaj w podwójnych kolumnach, z góry na dół, od strony lewej do prawej, zygzakiem. Oczywiście jest to przykład idealny i spotykany najczęściej w przypadku dłuższych inskrypcji (Rys. nr 2a). Jednak w wielu przypadkach teksty, towarzyszące wyrzeźbionym lub namalowanym scenom sa podzielone na fragmenty i rozproszone. Wówczas ustalamy porządek odczytu, biorąc pod uwagę nie tylko składnię i znaczenie glifów, ale i niekiedy ich rozmiary, gdyż większe bloki glificzne odnosiły się do najważniejszej z przedstawionych postaci, a mniejsze do osób drugoplanowych. W przypadku naczyń ceramicznych mamy często do czynienia z dwoma niezależnymi tekstami, z których jeden, umieszczony na brzegu naczynia, opowiada o jego poświęceniu, a drugi dotyczy ukazanej sceny. Niektóre teksty były też zapisywane $\mathrm{w}$ pojedynczej kolumnie lub $\mathrm{w}$ jednym wierszu, a nawet $\mathrm{w}$ formie lustrzanego odbicia lub plecionej maty. Z kolei na ogromnych kamiennych monolitach zwanych „zoomorfami”, kartusze z blokami glificznymi rozrzucone są na całej powierzchni (Rys. nr 2b) i należy bardzo uważnie ustalić kolejność odczytu inskrypcji.

a)

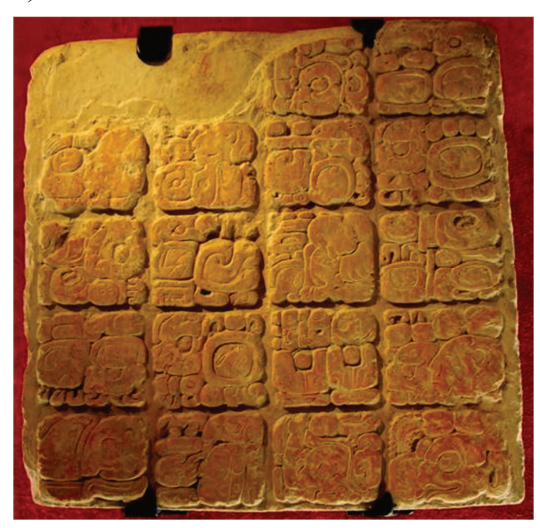

b)

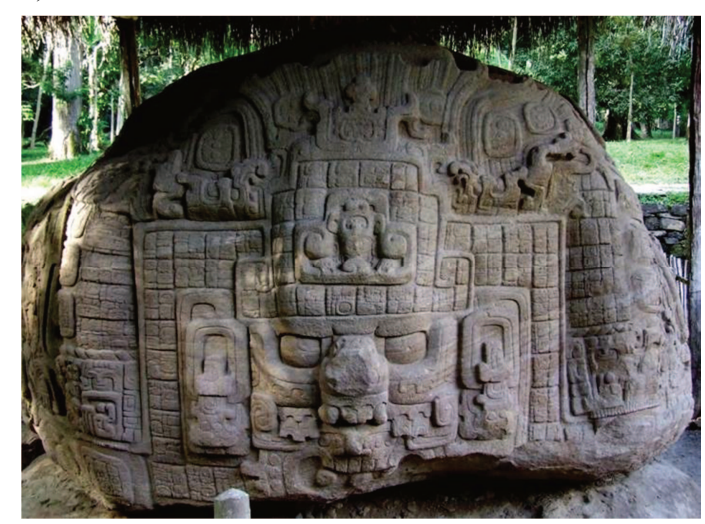

Rys. nr 2. Przykłady rozmieszczenia bloków glificznych: a) typowy tekst czytany w podwójnych kolumnach, b) tekst rozłożony na całej powierzchni monolitu ${ }^{1}$

Pismo Majów jest logo-sylabiczne, czyli obejmuje zarówno logogramy, jak i sylabogramy (znaki sylabiczne). Logogramy, oznaczające pełne słowa: rzeczowniki, przymiotniki i rdzenie czasowników, mają konstrukcję spółgłoska-samogłoskaspółgłoska, chociaż zdarzają się dłuższe wyrazy, zbudowane z trzech spółgłosek oddzielonych samogłoskami. Jako że pismo Majów było bardzo blisko związane

\footnotetext{
${ }^{1}$ Wszystkie fotografie zamieszczone w artykule zostały wykonane przez autorkę publikacji.
} 
z ikonografią, wiele logogramów oznacza dokładnie to, co przedstawia. Jest to dobrze widoczne w przypadku nazw zwierząt, określanych wizerunkami łba jaguara /BALAM ${ }^{2}$, papugi ary /MO\%, krokodyla /AHIN/ (Rys. nr 3a), węża /CHAN/, ryby /KAY/, kolibra /TZ'UNUN/, kwezala /(K'UK'/ czy skolopendry /CHAPAHT/. Część czasowników jest także stosunkowo łatwa do rozpoznania, gdyż, przykładowo, czasownik /CHOK/ (,rozsiewać, rozpraszać”) (Rys. nr 3b) w wyrażeniu chok ch'aaj, opisującym tak zwany rytuał symbolicznego zasiewu, przedstawiał glif ukazujący dłoń, z której spływają krople krwi lub wysypują się ziarna kukurydzy bądź grudki żywicy, palonej jako kadzidło. Z kolei czasownik il (,widzieć, być świadkiem”) przedstawiał profil gałki ocznej, ch'ak (,ścinać”) - siekierkę, a jatz’ (,rzucać, ciskać") - dłoń trzymającą kamień. Bardzo obrazowe przedstawienie niektórych logogramów spotykamy dla słów, oznaczających ,pić”/UK'/ lub ,jeść” /WE'/. W obu przypadkach mamy glify z wizerunkiem ludzkiej głowy, gdzie w miejscu ust znajduje się glif oznaczający „wodę” (dla czasownika $u k$ ') lub tortillę (dla czasownika we'. Z kolei logogram /PAS/ (,świt”) (Rys. nr 3c) stanowi w rzeczywistości połączenie trzech glifów: ziemi, słońca i nieba, aby wyrazić moment, kiedy to słońce ukazuje się tuż nad horyzontem, pomiędzy niebem a ziemią.

a)

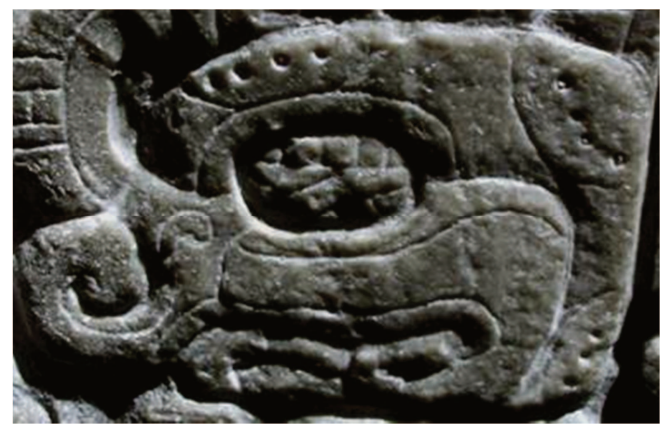

b)

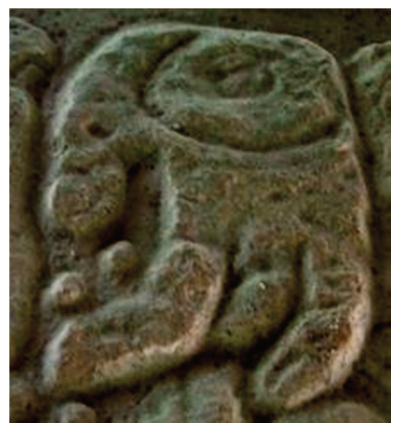

c)

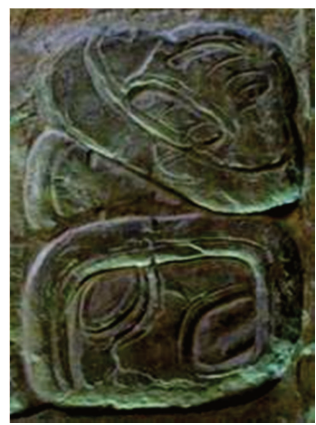

Rys. nr 3. Przykłady logogramów: a) rzeczownik /AHIN/ - „krokodyl, kajman”; b) czasownik /CHOK/ - „rozsiewać, rozpraszać”; c) rzeczownik /PAS/ - „świt”.

Również imiona majańskich bóstw zapisywano glifami, przedstawiającymi ich wizerunki zbliżone do tych, które spotykamy w scenach namalowanych na naczyniach ceramicznych lub wyrzeźbionych na zabytkach kamiennych. Zatem dzięki ikonografii łatwiej odczytać glify, a znając glify możemy lepiej zrozumieć różne elementy ikonograficzne. Poza tym, sceny ukazane na zabytkach Majów stanowią

\footnotetext{
${ }^{2}$ Zgodnie z zasadami przyjętymi w epigrafice Majów, logogramy zapisujemy dużymi wytłuszczonymi literami, a sylabogramy - małymi wytłuszczonymi literami (zob. Kettunen i Helmke, 2011:14-15).
} 
nie tylko ilustrację tekstu, ale często jego dopełnienie, gdyż z jednej strony niosą ze sobą dodatkowe informacje, które nie zostały wspomniane w inskrypcjach, a $\mathrm{z}$ drugiej strony pozwalają nam lepiej poznać pewne wydarzenia o charakterze religijnym, politycznym bądź społecznym.

Znaki sylabiczne, o konstrukcji spółgłoska-samogłoska ${ }^{3}$, mogą wydawać się nam bardziej abstrakcyjne, ale ich odczyt nawiązywał do słów, z których usunięto ostatnią spółgłoskę. I tak, na przykład, sylaba /hu/ przedstawiała łeb iguany, gdyż pochodziła od słowa huh (,,iguana”), sylabę /yo/ ukazywano jako liść, od słowa yop (,liść”), /ch'o/ to łeb myszy (Rys. nr 4a), gdyż ch'oh oznacza „mysz”, a /ba/ przedstawia łeb susła (Rys. nr 4b) od bah (,suseł”). Sylabę /pa/ można było zapisywać na dwa sposoby, jako glif wewnątrz zakreskowany, przypominający sieć, gdyż pochodziła od słowa pah (,sieć”) lub jako głowę klowna - od słowa $p a^{\prime}$ („,klown”). Oczywiście istnieje wiele znaków sylabicznych, które nie nasuwają nam żadnych skojarzeń, choć z pewnością inaczej były one postrzegane przez Majów.

a)

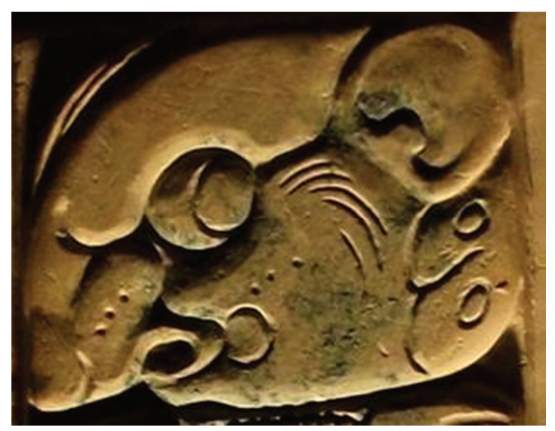

b)

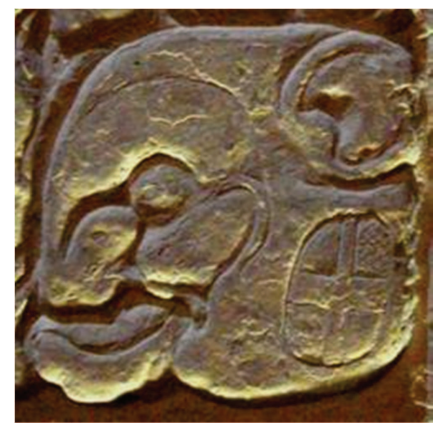

Rys. nr 4. Przykłady sylabogramów: a) sylaba /ch'o/; b) sylaba /ba/

Większość majańskich słów można było zapisać logogramami lub w pełni fonetycznie, czyli sylabami. Sylaby służyły też jako dopełnienia fonetyczne logogramów (Rys. nr 5), zamieszczane na początku, na końcu lub po obu stronach wyrazu, na przykład: /ka-KAN/, /CHAN-na/, /a-AJAW-wa/. Pojawiały się też jako określniki semantyczne, jak w przypadku glifu przedstawiającego łeb jaguara i mogącego być odczytywanym jako /BALAM/ lub /HIX/. Umieszczenie sylaby /hi/ przed logogramem wskazywało na odczyt /HIX/. Poza tym, sylaby funkcjonowały jako przyimki, afiksy zaimkowe, sufiksy instrumentalne, abstrahujące i deiktyczne, zmieniały rzeczowniki w formy przymiotnikowe lub podkreślały przynależność. Sylaby pełniły

\footnotetext{
${ }^{3}$ Samogłoski są również sylabogramami, gdyż rolę spółgłoski pełni tutaj znak zwarcia krtaniowego, który poprzedza samogłoskę, choć nie jest zaznaczany.
} 
też rolę sufiksów gramatycznych, które określały poszczególne formy czasownikowe, odmienne dla strony czynnej, biernej, mediopasywnej i antypasywnej, czasowników przechodnich i nieprzechodnich, w tym pozycyjnych, inchoatywnych, afektywnych czy imiesłowów.

a)

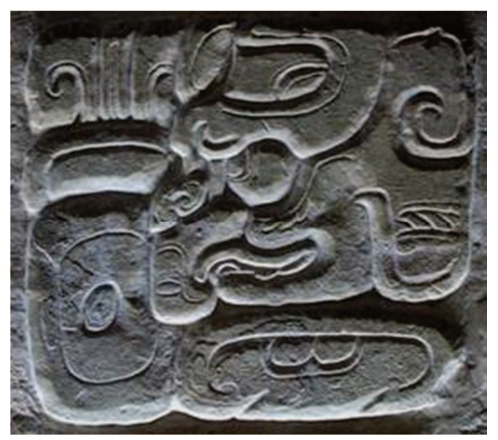

b)

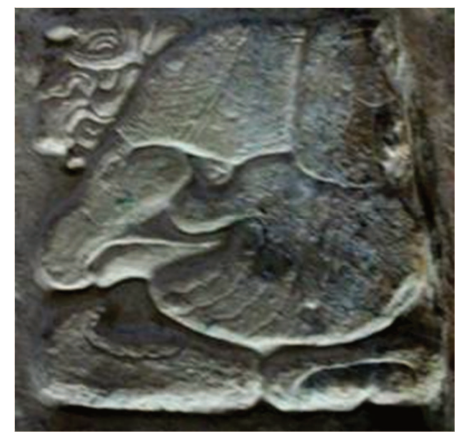

Rys. nr 5. Przykłady logogramów z sylabami jako ich końcowymi dopełnieniami fonetycznym; a) /SAK-HUN-na/, sak hu'un - oznaczające biała opaskę papierową, odpowiednik korony królewskiej; b) /AJAW-wa/, ajaw - „władca, osoba z najwyższej elity majańskiej”

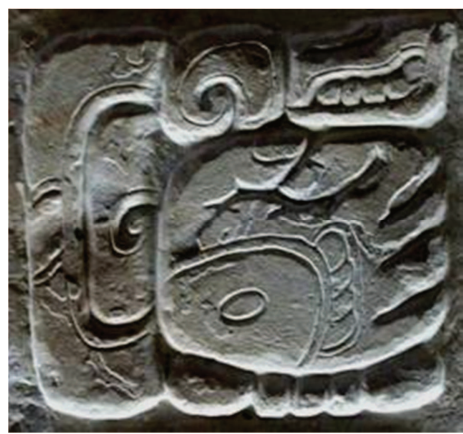

Rys. nr 6. Przykład odczytu bloku glificznego z glifem złożonym. Chociaż glify pojawiają się w kolejności: yi (po lewej) NAL-chi-la (po prawej, $\mathrm{z}$ góry na dół), to poprawnie należy odczytać je /yi-chi-NAL-la/, yichnal - „w obecności”

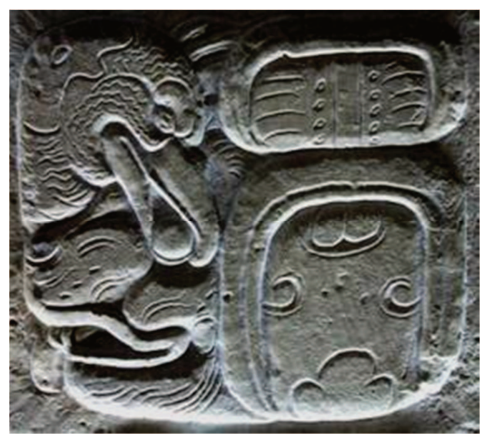

Rys. nr 7. Przykład elizji fonemowej w piśmie Majów. W bloku glificznym podano jedynie /i-tz'i-WINIK/, opuszczając sylabe /ni/ dla pełnego odczytu /i-tz'i-ni-WINIK/, itz'in winik „osoba młodszego brata"

W ramach danego bloku glificznego, gdy obejmuje on więcej znaków, odczytywanie rozpoczynamy od lewego, górnego rogu. Należy jednak uwzględnić bardzo dokładnie wzajemne rozmieszczenie poszczególnych glifów względem siebie oraz tak zwane glify złożone (na przykład logogramy: /AJAW/, /NAB/, /NAL/), które zostały przedstawione w inskrypcji jedynie częściowo i choć pojawiają się w górnej 
części bloku, to odczytywane są jako ostatnie. W takich przypadkach pomocne mogą okazać się końcowe dopełnienia fonetyczne logogramów (Rys. nr 6). Podczas pracy nad tekstem należy zwrócić też uwagę na elizję fonemową, gdyż w niektórych słowach ich końcowe spółgłoski h, j, l, m, n lub znak zwarcia krtaniowego niekiedy opuszczano i należy je zrekonstruować (Rys. nr 7).

a)

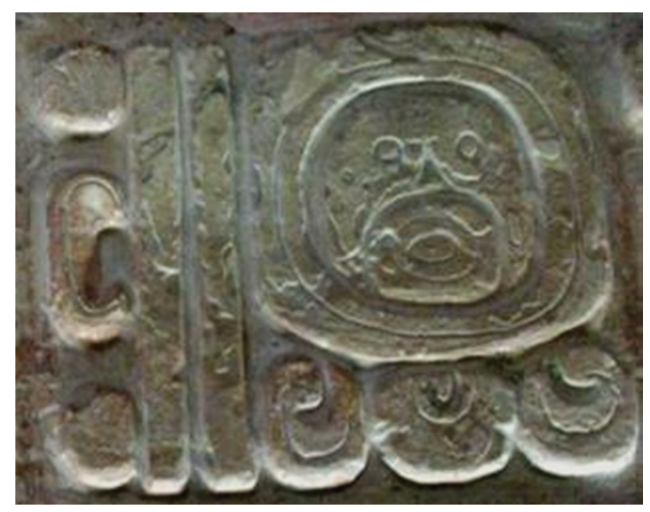

b)

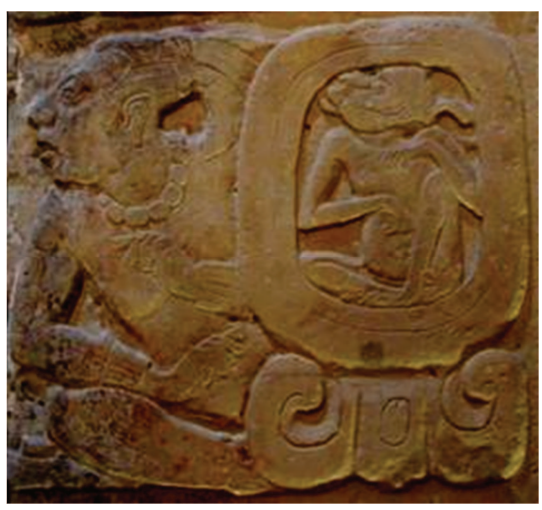

Rys. nr 8. Przykłady glifów podających dzień Ajaw z rytualnego kalendarza tzolk'in z towarzyszącymi im liczbami: a) dzień 12 Ajaw z liczbą zapisaną kropkami i kreskami oraz tradycyjnym glifem dnia; b) dzień 11 Ajaw zapisany glifami pełnofigurowymi

Zdecydowana większość glifów mogła być zapisywana na różne sposoby, jako formy proste i złożone. Niektóre glify miały wyjątkowo dużo alografów. Dla słowa ajaw, oznaczającego króla, władcę lub ogólnie osobę z najwyższej elity, istnieje kilkanaście różnych logogramów. Natomiast dla samogłoski /u/ skrybowie wprowadzili co najmniej 20 najróżniejszych form. Jako że inskrypcje Majów miały charakter narracyjny i pisano je $\mathrm{w}$ trzeciej osobie, a zatem samogłoska ta, pełniąca funkcję podmiotu w zdaniach przechodnich oraz zaimka dzierżawczego trzeciej osoby, najczęściej występowała w tekstach. Istnieją również tak zwane warianty głów zarówno antropomorficznych, jak i zoomorficznych, a nawet glify pełnofigurowe, w przypadku których szczególnie widoczne jest nawiązanie do ikonografii. Również liczby Majów, które w tradycyjny sposób zapisywane były za pomocą kombinacji kropek (dla „,") i kresek (dla „5”), mogły być przedstawiane jako głowy lub pełne wizerunki bóstw, które patronowały poszczególnym liczbom (Rys. nr 8). Glify pełnofigurowe nie były często spotykane, gdyż wymagały szczególnego kunsztu majańskich artystów, ale inskrypcje takie zachowały się na zabytkach w Copan (Honduras) (Rys. nr 9), Quirigua (Gwatemala), Palenque i Yaxchilan (stan Chiapas, Meksyk). 


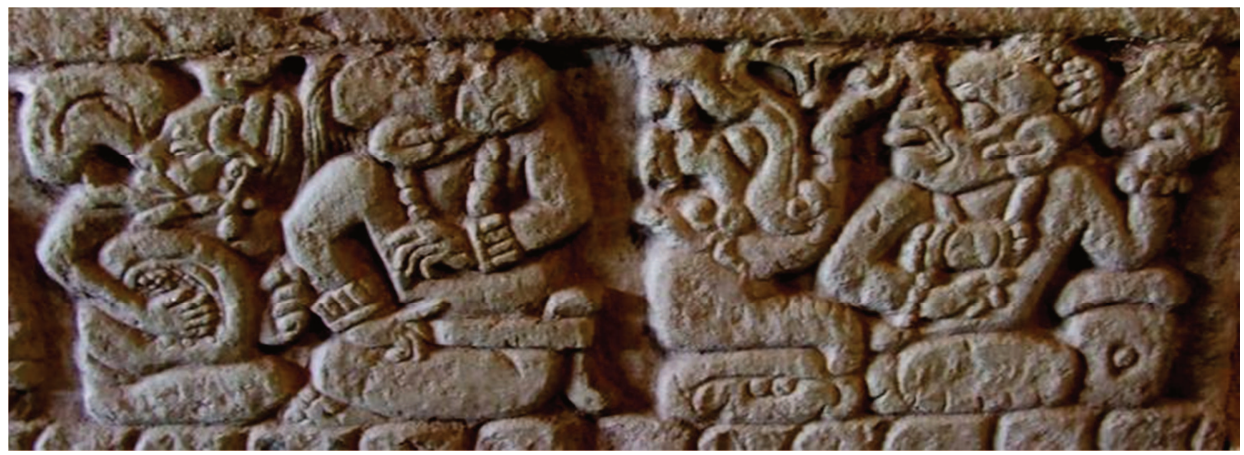

Rys. nr 9. Imię władcy Copan, Yax Pasaj Chan Yopaat zapisane glifami pełnofigurowymi jako /YAX-pa-sa//CHAN-na-YOPAT-ti/

Kolejną cechą pisma Majów jest wieloznaczność, a zatem spotykamy w nim homogramy i homofony. Jednym z najbardziej znanych homogramów jest glif, który w zależności od kontekstu może być odczytywany jako /TUN/, /ku/ lub /SIHOM/. Podobnie, glif przedstawiający głowę boga kukurydzy mógł oznaczać imię tegoż bóstwa, czyli /IXIM/, ale również liczbę /JUN/ (,jeden”), głównie w tekstach o charakterze kalendarzowym lub sylabę /na/, szczególnie w inskrypcjach namalowanych na naczyniach ceramicznych. Homofonami były, na przykład, różne glify, które oznaczały „niebo”, „węża” lub liczbę „cztery”, które są odczytywane jako chan i stosowane niekiedy wymiennie, na zasadzie rebusu. Zapisy w formie rebusu, kiedy to ważne było nie znaczenie słowa, a jedynie jego brzmienie, również były typowe dla pisma Majów, czego potwierdzenie znajdujemy w przypadku imienia bóstwa Yopaat, które mogło być zapisane logogramem /YOPAT/ lub dwoma logogramami /YOP-AT/, które dawały takie samo brzmienie, bądź dla logogramu /TIL/, który przedstawia łeb tapira i faktycznie oznacza to zwierzę, choć na zasadzie rebusu pojawiał się jako czasownik til (,„palić”), brzmiący tak samo.

Niektóre glify były też jednocześnie używane jako logogramy i sylabogramy. Wówczas, w oparciu o kontekst, należy ustalić, która z form została użyta, na przy$\mathrm{kład:} \mathrm{/ba/} \mathrm{czy} \mathrm{/BAH/,} \mathrm{/ka/} \mathrm{czy} \mathrm{/KAY/,} \mathrm{/a/} \mathrm{czy} \mathrm{/AJ/,} \mathrm{/yo/} \mathrm{czy} \mathrm{/YOP/.} \mathrm{Poszczególne}$ glify mogły pojawiać się $\mathrm{w}$ danym bloku w swych formach prostych lub bardziej skomplikowanych, ale i tutaj znajdujemy różne sposoby ich wzajemnego ustawienia. Niekiedy glify pojawiają się jako infiksy, czyli umieszczane wewnątrz innego glifu (Rys. nr 10a) i wówczas zazwyczaj, choć nie zawsze, odczytujemy je najpierw. Majowie stosowali również zasadę pars pro toto bądź łączyli ze sobą dwa różne glify, najczęściej logogramy, przy czym z drugiego pozostawał jedynie drobny, charakterystyczny fragment. Na przykład, rzeźbiarze z Palenque najczęściej zapisywali imię króla Kan Bahlam („Wąż Jaguar”), przedstawiając głowę węża /KAN/, do której dołączono jedynie uszy jaguara i ewentualnie sylabę /ma/ jako dopełnienie fone- 
tyczne, sugerujące razem logogram /BALAM/ (Rys. 10b). Natomiast jeśli w danym słowie pojawiały się po sobie dwie identyczne sylaby, to zapisywano jedynie jedną sylabę z dodaniem po lewej stronie dwóch kropek jako znaku diaktrycznego, wskazującego na konieczność podwojenia sylaby (Rys. nr 10c).

a)

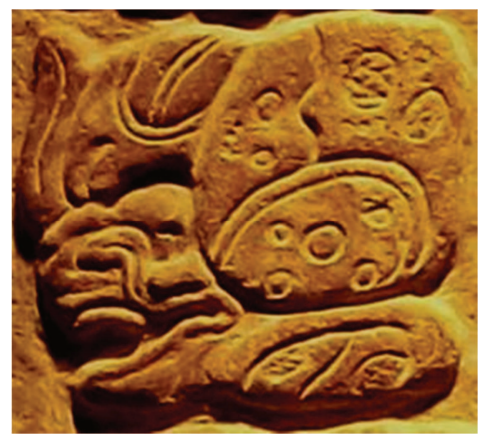

b)

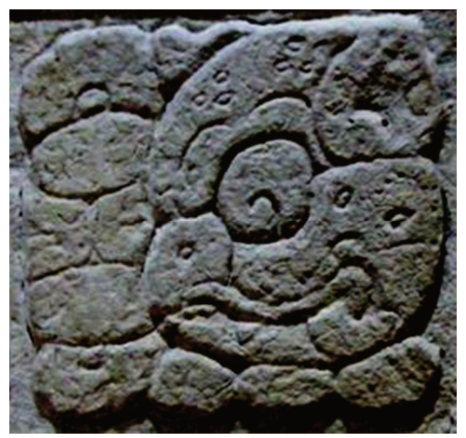

c)

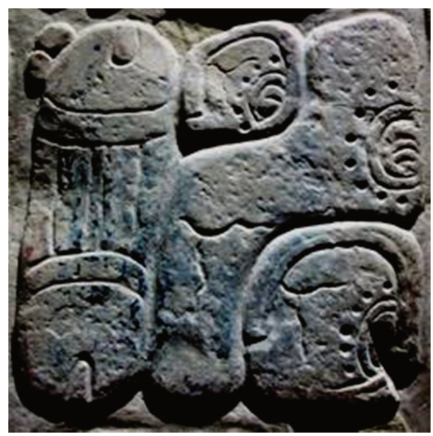

Rys. nr 10. Przykłady kompozycji glifów w ramach bloku glificznego: a) sylaba /bi/ (przedstawiana jako quincunx) została umieszczona jako infiks w logogramie /WAY/; b) po prawej stronie połączono logogramy /KAN/ (,wąż”) i /BALAM/ (,jaguar”), choć z drugiego ukazano jedynie ucho jaguara i końcowe dopełnienie fonetyczne /ma/ (trzy kropki w dolnej części bloku glificznego); c) glif po lewej stronie przedstawia sylabę /ko/ z dołączonymi u góry dwiema kropkami, wskazującymi na podwojenie sylaby

a)

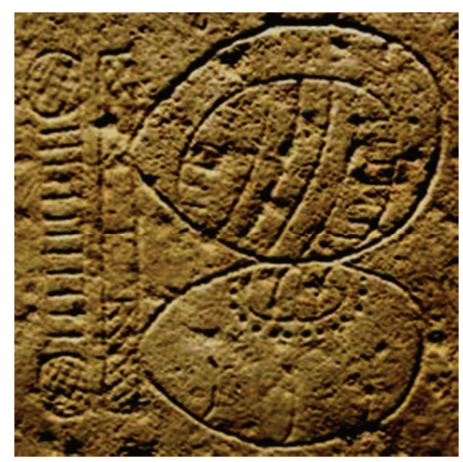

b)

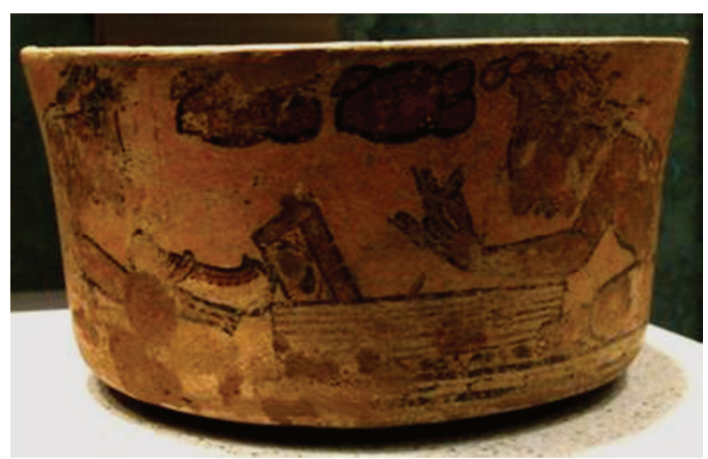

Rys. nr 11. a) Glify /AJ-tz'i-ba/, ajtz'ihb - „skryba-malarz”; b) naczynie ceramiczne Majów przedstawiające skrybę-malarza podczas pracy nad manuskryptem

Te wszystkie cechy pisma Majów sprawiały, że skrybowie i rzeźbiarze mogli stosować najróżniejsze formy glifów, od najprostszych do coraz bardziej wypracowanych oraz łączyć je, tworząc wiele odmiennych kombinacji i wykazując swą inwencję twórczą. Niekiedy imiona władców, składające się z kilku członów, można było zapisywać 
na kilka lub nawet kilkanaście sposobów. Niektórzy majańscy skrybowie-malarze zwani ajtz’ihb (Rys. nr 11) i rzeźbiarze ajuxul wyróżniali się szczególnie piękną kaligrafią, dzięki czemu inskrypcje wyglądały niezwykle ciekawie ze względów estetycznych. Chociaż wielu z nich podawało swoje imiona (Rys. nr 12), to niestety anonimowymi pozostają dla nas wspaniali rzeźbiarze, którzy byli autorami pięknych glifów pełnofigurowanych we wspominanych już ośrodkach: Palenque, Quirigua czy Copan.

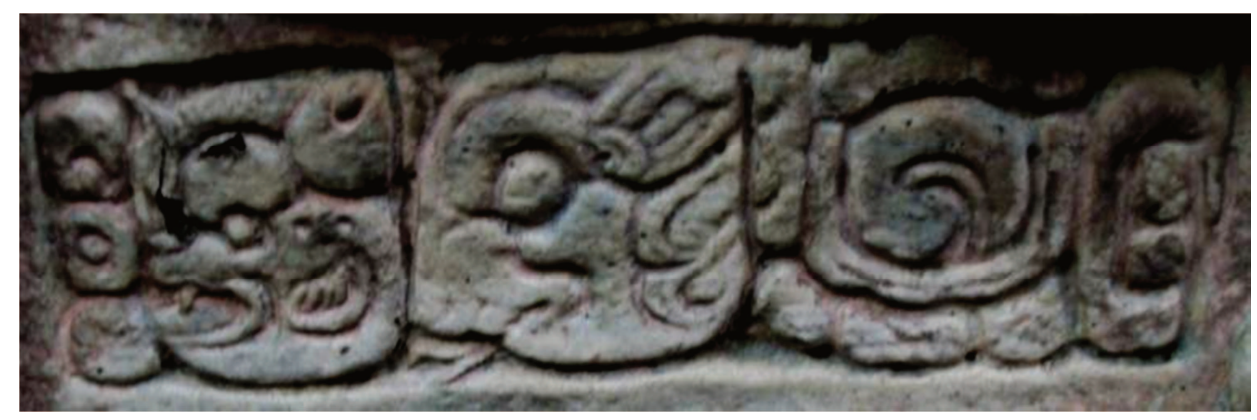

Rys. nr 12. Przykład podpisu rzeźbiarza, zaczynający się od słowa /yu-xu[lu]/, yuxul - ,jego rzeźba”, po którym podano imię artysty

Obecnie pismo Majów jest odczytane w 60-80\% (Kettunen i Helmke, 2011:23). Dolna granica odnosi się do tych glifów, z których można ułożyć pełne słowa w języku majańskim i przetłumaczyć je. Niekiedy zdarza się jednak, że pomimo odczytania glifów, można przypisać im tylko przypuszczalne znaczenie. Przykładami mogą być tytuły używane przez przedstawicieli elity, jak kaloomte’ czy sajal, z których pierwszy stanowi najbardziej prestiżowy tytuł, porównywalny z ,imperatorem”, a drugi określa osoby zarządzające ośrodkami drugorzędnymi, choć nie wiemy z całkowitą pewnością, jak były one pojmowane przez dawnych Majów. Z kolei, biorąc pod uwagę składnię zdania, można określić, czy dany glif, nawet nie będąc odczytanym, stanowi orzeczenie czy część podmiotu. Dzięki temu udaje się parafrazować pewne fragmenty tekstu. Jako przykład może posłużyć glif, przedstawiający znak „gwiazdy”, umieszczony nad glifami ,ziemi” lub emblematu miasta. Nazywany jest przez epigrafików glifem ,gwiezdnej wojny” i określa działania wojenne o wyjątkowo destrukcyjnym charakterze. Najwięcej trudności przysparzają szczególnie te glify, które podają imiona bóstw i najróżniejszych istot mitologicznych, związanych z bardzo bogatym i nie zawsze dla nas zrozumiałym systemem wierzeń dawnych Majów.

Do chwili obecnej nie ma całkowitej zgodności wśród uczonych w sprawie podstawowych zasad ortografii i pewnych zagadnień fonetycznych (zob. np. Houston et al., 2000; Kettunen i Helmke, 2011:64-66). Jak wiemy, majańskie słowa kończą się spółgłoskami. W przypadku, gdy wyraz zapisywany jest sylabami o takich samych samogłoskach, na przykład /k’a-ba/, lub logogramem, który podobnie jak jego koń- 
cowe dopełnienie fonetyczne mają jednakowe samogłoski, na przykład /CHAN-na/, nie ma wątpliwości, że słowa odczytujemy, odpowiednio, $k$ 'ab i chan. Znacznie bardziej skomplikowane są przypadki, gdy mamy do czynienia z niezgodnością samogłosek, gdyż prowadzi to do pojawienia się długich samogłosek, znaków zwarcia krtaniowego lub samogłosek dźwięcznych. Zdarza się zatem, że różni badacze proponują nieco inne sposoby rekonstrukcji tego samego wyrazu. Przykładowo, dla słowa oznaczającego „krzemień” i zapisywanego glificznie jako /to-k’a/, spotykamy w literaturze kilka odmiennych transkrypcji, jak: took', to 'k' lub to 'ok'

Pismo glificzne Majów rozwijało się w miarę upływu wieków. Pierwsze teksty były bardzo krótkie i zawierały głównie logogramy, podające imiona i tytuły władców. Nie występowały też sufiksy wskazujące na odmienne formy czasownikowe. Dopiero z czasem zaczęła pojawiać się większa liczba słów zapisywanych sylabicznie. Pomimo to pismo Majów nigdy nie utraciło swej jednolitości. Chociaż badania paleograficzne dowodzą wielu różnic, występujących na poszczególnych obszarach geograficznych lub w pewnych okresach, to jednak zawsze był to ten sam system pisma (Lacadena i Wichmann, 2002: 313).

Pismo Majów było narzędziem w ręku elity rządzącej. To władcy sprawowali pieczę nad artystami i decydowali, czy dana inskrypcja miała zostać umieszczona w miejscu publicznym bądź w całkowicie prywatnym, dostępnym tylko dla osób blisko związanych z dworem królewskim.

\section{Treść majańskich inskrypcji}

Do dnia dzisiejszego zachowały się tysiące najróżniejszych inskrypcji wyrzeźbionych, wyrytych, namalowanych i wymodelowanych w stiuku, a kolejne są nadal odkrywane przez archeologów. Teksty wyrzeźbione w kamieniu spotykamy na wielu elementach architektonicznych (fasadach budowli, gzymsach, odrzwiach, nadprożach, kolumnach, ławach i schodach), na panelach ściennych, znacznikach boisk do gry w piłkę, ołtarzach, a przede wszystkim na monolitach zwanych stelami, które mogły osiągać wysokość nawet dziesięciu metrów. Inskrypcje malowano na naczyniach ceramicznych (Rys. nr 13a), ścianach budowli, jaskiń i grobowców, na kamieniach szczytowych, tkaninach oraz na stronach manuskryptów zwanych kodeksami (Rys. 13b). Teksty ryto również na drobnych przedmiotach z muszli, jadeitu, obsydianu, pirytu, łupków czy kości.

Treść majańskich inskrypcji w pewien sposób zależy od tego, na jakich mediach je zamieszczano, ale nawet te najskromniejsze dostarczają wielu cennych informacji. Najkrótsze teksty, zwane „etykietkami”, o bardzo prostej konstrukcji zdań, pochodzą z artefaktów, które stanowiły prywatną własność przedstawicieli elity. Zazwyczaj podają one nazwę przedmiotu i imię właściciela, dzięki czemu możemy poznać, jakimi słowami określali Majowie naszyjniki, ozdoby uszu lub zwierciadła. 
a)

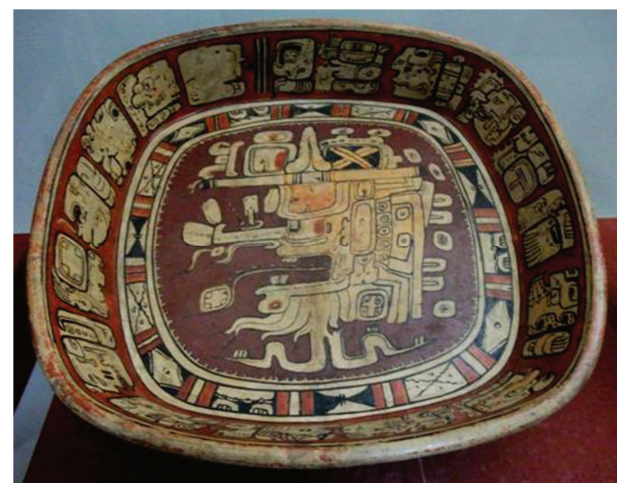

b)

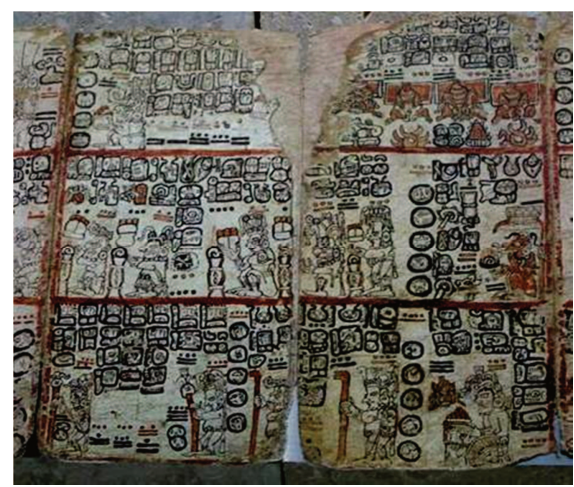

Rys. 13. Przykłady malowanych inskrypcji: a) naczynie ceramiczne; b) strony majańskiego manuskryptu znanego jako Kodeks Madrycki

Brzegi wielu naczyń ceramicznych zdobiono tekstami, które wspominały o ich poświęceniu, podawały rodzaj naczynia (wazę, talerz bądź talerz na trójnogu) i jego przeznaczenie, na przykład, do picia kakao, przygotowywanego na różne sposoby i odpowiednio doprawianego do smaku. Wymieniano też imię i tytuły właściciela. Niekiedy scenom ukazanym na naczyniach towarzyszyły też dodatkowe teksty, które opowiadały o wydarzeniach mitycznych lub historycznych. Z kolei kamienie szczytowe ozdabiano wizerunkami bóstw, a towarzyszące im inskrypcje wspominały akt poświęcenia domu.

Największa liczba inskrypcji wyrzeźbionych w kamieniu pochodzi z lat 600-800 n.e. Wyróżniają się tutaj stele, które upamiętniały upływający czas i były wznoszone co 5, 10, 15, a przede wszystkim 20 lat. Stele mogły być rzeźbione z jednej, dwóch, trzech lub nawet czterech stron, a zatem długości tekstów były różne (Rys. nr 14). Poza informacją o samym poświęceniu steli, opisywały najróżniejsze rytuały, na przykład, symbolicznego zasiewu, samoofiary z krwi, przywoływania bogów i duchów przodków czy personifikacji istot nadprzyrodzonych, podając przy tym imiona i tytuły władców. W przypadku dłuższych inskrypcji możemy dowiedzieć się o wielu wydarzeniach z życia królów i poznać ich genealogie. Towarzyszące stelom ołtarze często przedstawiały postacie związanych jeńców, pojmanych podczas działań wojennych. O wojnach i ceremoniach wspominały też inskrypcje wyrzeźbione na kamiennych lub drewnianych nadprożach.

Teksty na panelach ściennych (Rys. nr 15) opowiadały o najróżniejszych ceremoniach, poświęcaniu budowli lub miejsc pochówku, o dziejach dynastii, gdzie wydarzenia historyczne przeplatały się z mitycznymi. Na szczególną uwagę zasługują też bardzo długie inskrypcje, wyrzeźbione na stopniach schodów prowadzących na szczyty świątyń. Bardzo często przekazywały one nie tylko informacje o działaniach wojennych, ale i przedstawiały epizody z życia kilku pokoleń władców (Rys. nr 16). 
a)

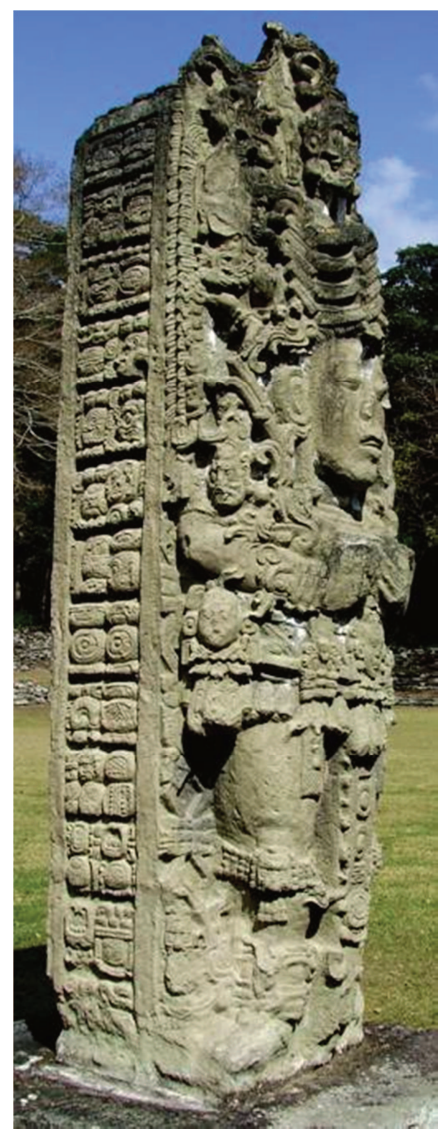

b)

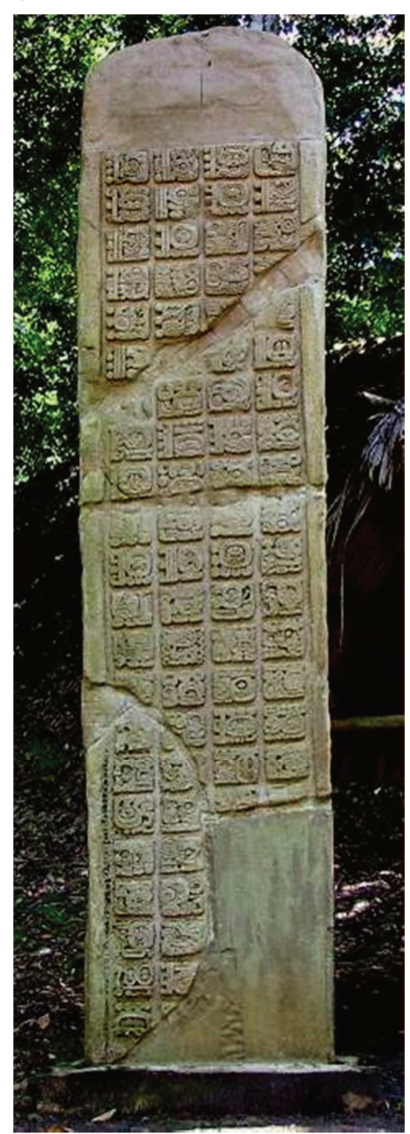

c)

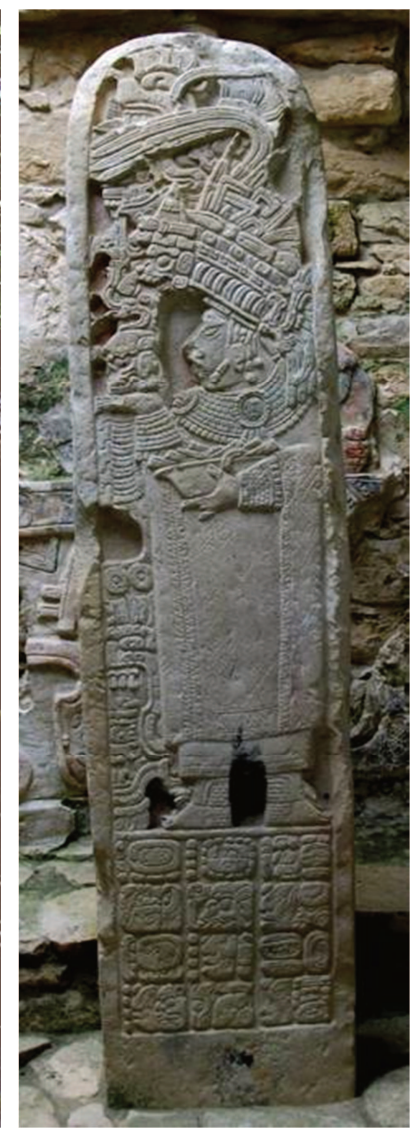

Rys. nr 14. Stele Majów: :a) Stela A z Copan (Honduras); b) Stela 8 z Dos Pilas (Gwatemala); c) Stela 35 z Yaxchilan (stan Chiapas, Meksyk)

Jako że pismo glificzne Majów było bardzo związane z instytucją ,boskiego władcy" (k'uhul ajaw), gdy autorytet ten znacznie osłabł, pewnej zmianie uległa też treść inskrypcji. Pod koniec późnego okresu klasycznego, w ośrodkach leżących na północy Jukatanu powstawało coraz mniej tekstów rzeźbionych w kamieniu. Stały się one znacznie krótsze i nabrały bardziej bezosobowego charakteru, a nawet zaczęły pojawiać się tak zwane ,pseudoglify”, które jedynie naśladowały wyglądem glify, a w rzeczywistości były pozbawione jakiegokolwiek znaczenia i wymyślone przez skrybów (Grube 2002:351). Tradycja piśmiennicza jednak przetrwała, czego dowodem są manuskrypty Majów, pochodzące z okresu postklasycznego. Do naszych czasów przetrwały jedynie cztery majańskie kodeksy, zawierające almanachy wróżbiarskie, tablice zaćmień Słońca i Księżyca oraz tablice planety Wenus, choć z pewnością Majowie mieli również rękopisy, które mogły, na przykład, zawierać dzieje dynastii. 


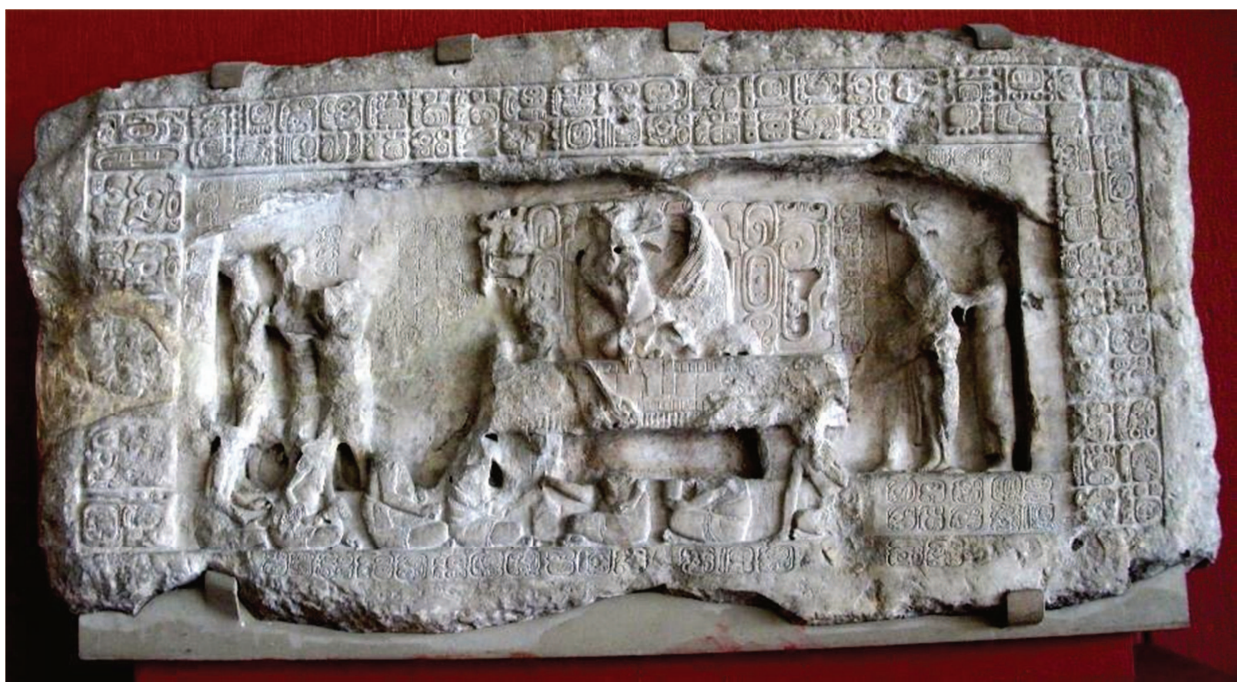

Rys. nr 15. Panel 3 z Piedras Negras (Gwatemala)

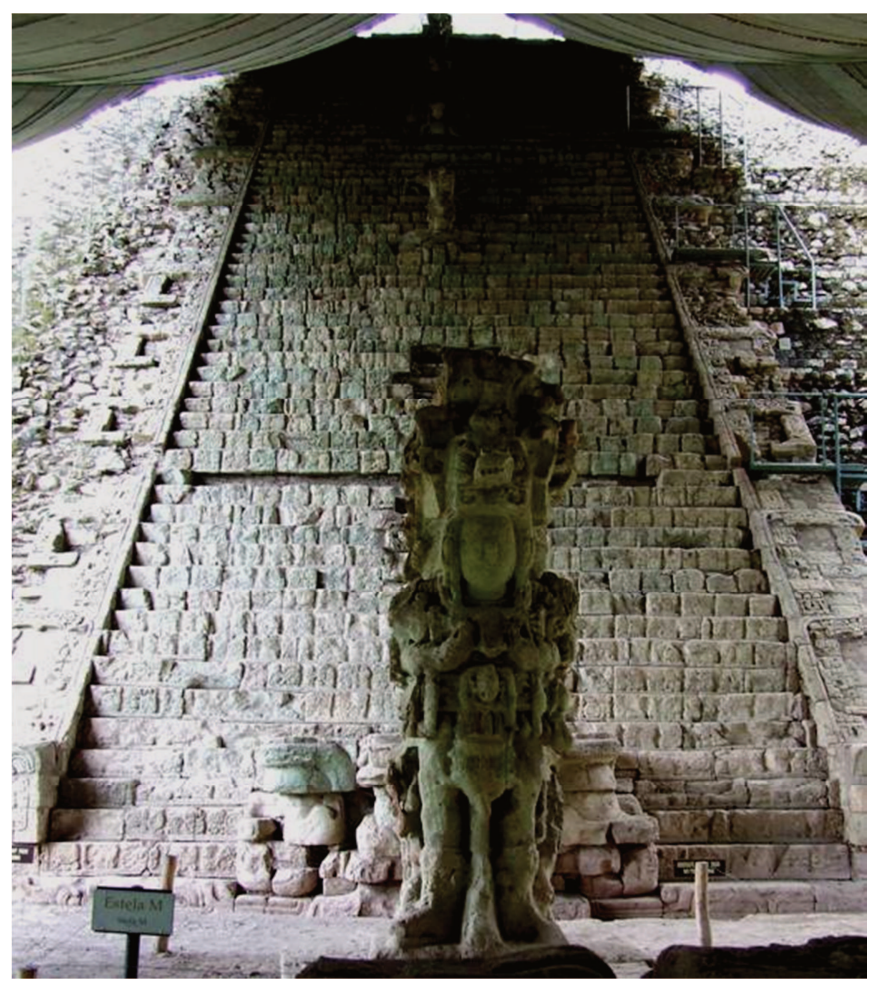

Rys. nr 16. Na schodach Świątyni 26 w Copan (Honduras) wyrzeźbiono najdłuższą ze znanych inskrypcji Majów 
Dzięki tak wielkiej różnorodności inskrypcji glificznych poznajemy zarówno świat wierzeń dawnych Majów, ich bóstwa i rytuały, jak imiona i tytuły władców, ich związki pokrewieństwa, daty narodzin, objęcia tronu i śmierci. Dowiadujemy się o kluczowych wydarzeniach historycznych w licznych królestwach, o prowadzonych wojnach, a dzięki temu o sytuacji politycznej i relacjach pomiędzy poszczególnymi ośrodkami. Jednocześnie dokładna analiza inskrypcji pozwoliła dostrzec piękno języka, w którym zostały one spisane.

\section{Literacki charakter inskrypcji Majów}

Kiedy spora część glifów została już odczytana, uczeni zaczęli zastanawiać się, czy inskrypcje Majów, zwłaszcza te długie o charakterze narracyjnym, można uznać za teksty literackie. Kathryn Josserand (1991: 12-31) zwróciła uwagę na teksty wyrzeźbione na ogromnych panelach, zdobiących trzy świątynie tak zwanej Grupy Krzyża w Palenque. Dostrzegła wówczas poetyckie strofy, grę słów, wypracowane formy czasownikowe, metafory i dwuwiersze, które są typowe dla rytualnego języka współczesnych Majów. Poszczególne, ujęte w ramy czasowe epizody były ze sobą wspaniale powiązane, niektóre wydarzenia specjalnie podkreślane, a zmiany w typowej składni wpływały na wagę przekazywanych informacji. Równie poetycki charakter cechował też teksty wyrzeźbione na innych zabytkach w Palenque, w tym na panelach w Pałacu i w Świątyni Inskrypcji. Z kolei Clemency Coggins (1992: 101) podkreślała przykłady paralelizmu widoczne $w$ dwuwierszach i czterowierszach, które zawierała inskrypcja na Steli A z Copan, opisująca rytuały związane $\mathrm{z}$ czterema stronami świata.

O poetyckości tekstu wyrzeźbionego na Panelu 96 Glifów w Palenque wspominały Linda Schele i Maricela Ayala (1993: 25-27). W inskrypcji tej wyróżniają się warianty glifów użyte dla słowa $t z$ ' $a k \mathrm{w}$ wyrażeniu $u t z$ 'akaj, poprzedzającym liczbę dni, które upłynęły pomiędzy jednym wydarzeniem a kolejnym (Rys. nr 17a). Zamiast typowego logogramu /TZ'AK/ pojawiają się kombinacje glifów jako elementów wzajemnie się uzupełniających i tworzących całość: „niebo-ziemia” jako „przestrzeń”, „dzień-noc” jako „czas”, „kobieta-mężczyzna” jako „kompletna para”, „gwiazdy-księżyc” jako „ciała niebieskie” (Rys. nr 17b), „tortilla-woda” jako „pożywienie" (Hull, 2003: 446) bądź też jako elementów, z których drugi stanowi konsekwencję pierwszego: „chmura-deszcz”, „wiatr-deszcz” (Rys. nr 17c), niedojrzały/zielony-dojrzały/żółty" (w nawiązaniu do kukurydzy") (Stuart, 2003). Warto też podkreślić, że końcowy fragment inskrypcji na Panelu 96 Glifów podaje, że artysta „ozdobił glify-słowa”. Ozdobienie to mogło zatem odnosić się nie tylko do wspaniałej kaligrafii, którą wyróżniają się same glify, ale i do użytych figur stylistycznych i piękna języka. 
a)

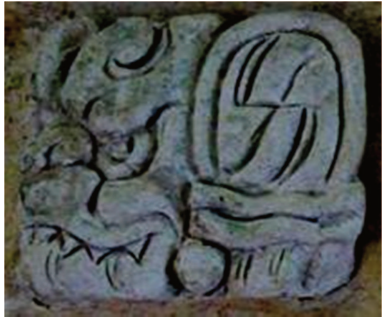

b)

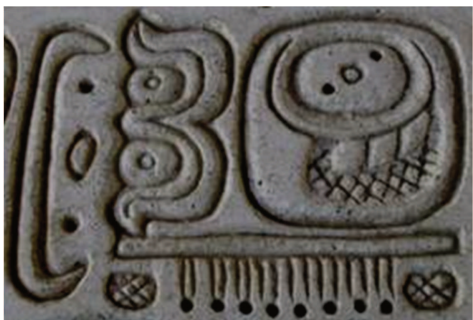

c)

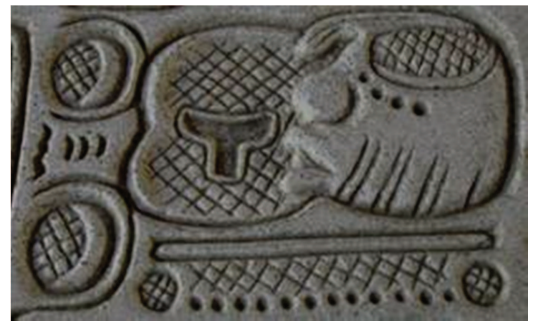

Rys. nr 17. Przykłady odmiennych zapisów wyrażenia utz'akaj: a) tradycyjny zapis /u-TZ'AK-AJ/; b) glify /EK'/ (,gwiazdy”) i /UH/ (,,księżyc”) zastępujące typowy logogram /TZ'AK/; c) glify /IK'/ (,wiatr”) i /HA'/ (,,deszcz”) zastępujące typowy logogram /TZ'AK/

Dokładną analizę majańskich inskrypcji pod względem ich poetyckiego charakteru przeprowadzili Kerry Hull i Alfonso Lacadena, którzy doszukali się najróżniejszych figur retorycznych, świadczących o wyjątkowej złożoności i pięknie literackich tekstów Majów, a tym samym o artyzmie skrybów i rzeźbiarzy (Hull, 2003; Lacadena, 2009; Lacadena i Hull, 2012). Wspomniani uczeni wyróżnili takie figury stylistyczne, jak: alegoria, aliteracja, anafora, anastrofa, antymetabola, chiazm, elipsa, enallage, epifora, hiperbaton, hiperbola, homeoptoton, metafora, metonimia, personifikacja, poliptoton czy zeugma.

Przykładami anafory spotykanej w inskrypcjach mogą być frazy zaczynające się takim samym czasownikiem, ale innymi podmiotami, jak yila' k'uhul mutal ajaw, yila' waxak winik ajawtaak (,,widział to boski władca Mutul, widziało to 28 panów”)

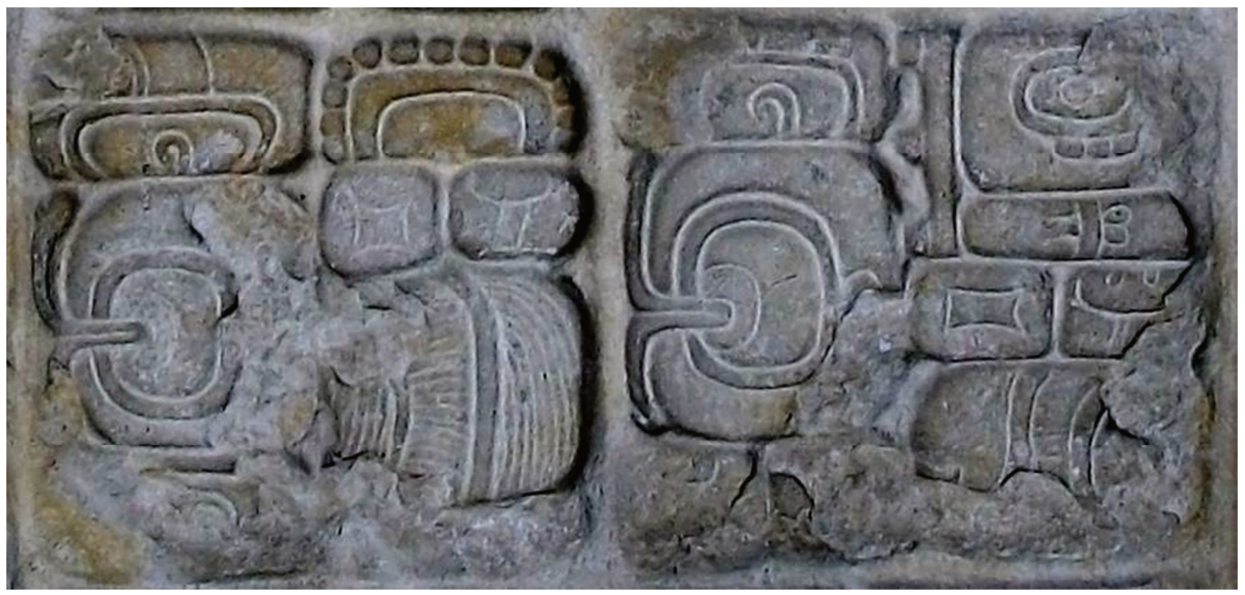

Rys. nr 18. Fragment inskrypcji wyrzeźbionej na Steli 4 z Ixtutz (Gwatemala) jako przykład anafory: /yi-IL-a-K'UH-MUT-AJAW-wa//yi-IL-a-8-WINAK-ki-AJAW-TAK/, yila' k'uh[ul] mut[ul] ajaw, yila' waxak winak ajawtaak, ,widział to boski władca Mutul, widziało to 28 panów” 
(Lacadena, 2009: 37) (Rys. nr 18) bądź fragmenty listy tytularnej władców, gdzie wyrażenie ucha'n (,gwardian”) zostało użyte kilkakrotnie, choć za każdym razem pojawia się po nim imię innego jeńca. Alfonso Lacadena natrafił też w Kodeksie Drezdeńskim na przykłady synonimów dla słowa oznaczającego ,zapowiedź, zwiastun". W jednym z almanachów wróżbiarskich majańscy skrybowie użyli synonimów: muut, mu'uk i muwak, stanowiących jednocześnie przykład aliteracji (Lacadena, 2009: 35-36). Ten sam autor zwraca również uwagę na zwroty takie, jak witziij ujolil („,zaszki ułożone w stos niczym góra”), wskazujące na użycie hieprboli (Lacadena, 2009: 41).

$\mathrm{W}$ inskrypcjach Majów spotykamy wiele difrasismos. Słowo to, pochodzące z języka hiszpańskiego, zostało specjalnie wprowadzone przez badaczy języków Mezoameryki do określenia specjalnej konstrukcji gramatycznej, która obejmuje połączenie dwóch słów o odrębnym znaczeniu w celu utworzenia innego wyrażenia o charakterze metaforycznym. Przykładami takich difrasismos w majańskich tekstach są: k'in-haab (,dzień-rok”) w znaczeniu „,pełni czasu”, pohp-tz'am („matatron”) jako „władza, autorytet”, kab-ch'een (,ziemia-grota”) jako określenie „miasta, terytorium”, chan-ch'een (,niebo-grota”) (Rys. nr 19a) dla oznaczenia najbardziej sakralnej części miasta, took'-pakal („,krzemień-tarcza”) jako „armia” bądź chanal k'uh-kabal k'uh („bogowie nieba-bogowie ziemi”) (Rys. nr 19b) do wyrażenia „wszystkich bogów” (Hull, 2002: 414-438; Lacadena i Hull, 2013: 13-16). Istnieje również wyrażenie obejmujące trzy słowa, chan-kab-ch'een (,niebo-ziemiagrota"), które Hull uważa za odnoszące się do wszechświata.

a)

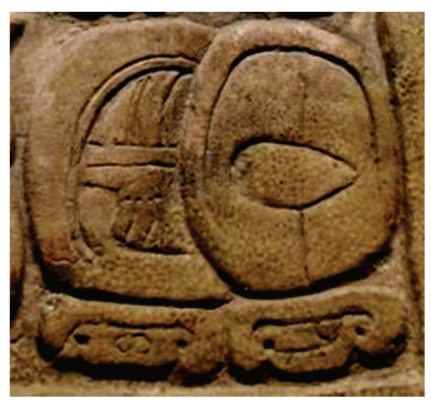

b)

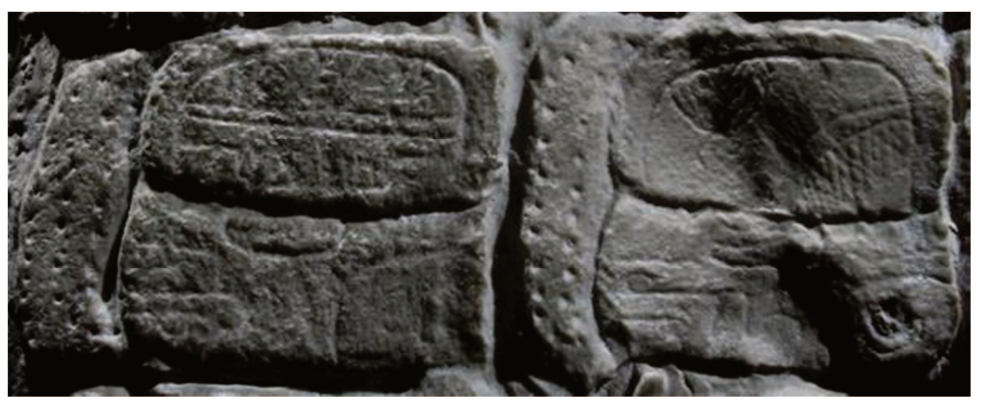

Rys. nr 19. Przykłady difrasismos: a) /CHAN-na-CH'EN-na/, chan-ch'een jako określenie najbardziej sakralnej części miasta; b) /K'UH-CHAN-K'UH-KAB/, k'uh chan [al], k'uh kab [al] jako określenie wszystkich bogów

Dzięki stosowaniu najróżniejszych form stylistycznych język stawał się bardziej obrazowy czy wręcz emocjonalny, a same inskrypcje wyróżniały się nie tylko z czysto wizualnego, estetycznego punktu widzenia, ale i lingwistycznego. Majań- 
scy skrybowie i rzeźbiarze mogli zatem przekazać tę samą treść, posługując się różnymi zwrotami, od bezpośrednich do metaforycznych. Na przykład, w tekstach o charakterze genealogicznym, wspominających matkę władcy, można było napisać po prostu yal, czyli dosłownie ,on (jest) dzieckiem (matki)” (Rys. nr 20a), choć często posługiwano się zwrotem ubaah ujuntahn (,on jest osobą jej troski/miłości”) (Rys. nr 20b), czy nawet ubaah uch'ahb yak'ab (,on jest wizerunkiem jej mocy prokreacji”).

a)

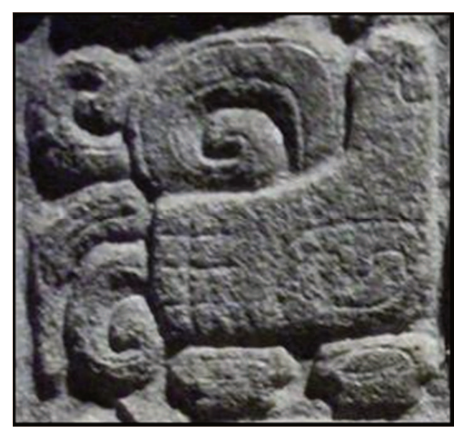

b)

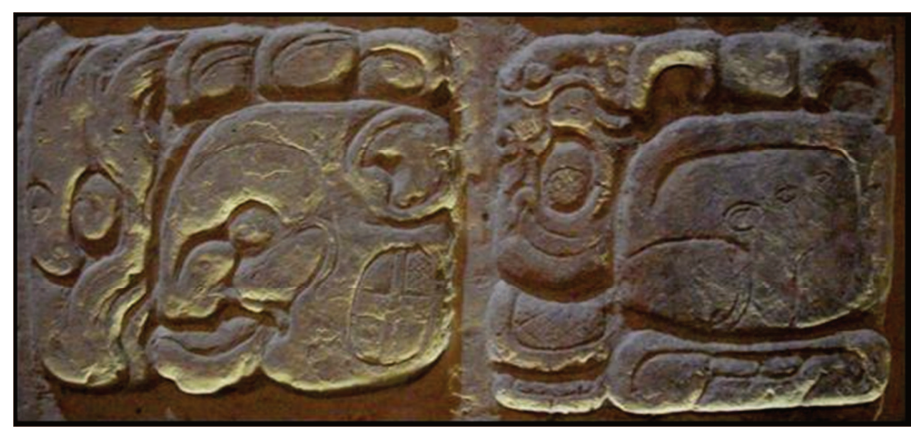

Rys. nr 20. Przykłady odmiennych wyrażeń dla określenia ,dziecka matki”: a) /ya-AL-la/, yal; ,on/ona jest dzieckiem matki”; b) /u-BAH-hi/ /u-1-TAN-na/, ubaah ujuntahn, „ona/ona jest osobą jej troski/miłości"

Objęcie władzy można było wyrazić za pomocą wielu różnych określeń, jako: uk'alaw sak hu'un tu baah (,obwiązał białą opaskę (odpowiednik korony) wokół głowy”), johyaj ti ajaw (,zadebiutował jako król”), chumwaan ta ajawlel (,zasiadł w królestwie”), uch 'amaw k'awiil (,wziął sceptr z wizerunkiem boga K'awiil”) czy ajawaniiy (,stał się królem”). Moment śmierci też można było opisać po prostu czasownikiem cham (,umierać”) lub metaforycznie jako och ha' (,wkroczenie w wody ('świata podziemnego)"), och bih (,,wkroczenie na drogę (prowadzącą w zaświaty)”), czy też jako k'a'aay usak ik'il (,,ulotniło się jego czyste tchnienie”). Działania wojenne przedstawiano jako och uch'e'en (,wkraczanie do groty (naturalnej lub sztucznej jaskini jako najbardziej sakralnego zakątka miasta)"), jubuuy utook'-pakal (,została rozbita jego armia”), ch'ak (,zniszczenie/ścięcie”), nak (,podbój”), pul (,spalenie”), chuk (,pojmanie” w przypadku jeńców) lub jako „gwiezdną wojnę”.

Kerry Hull (2003: 379) podkreśla, że figury retoryczne były szczególnie ważne dla ustnego przekazu tekstów. Z zapisków kronikarzy wiemy, że kapłani sprawdzali w swych księgach przepowiednie, odpowiednio je interpretowali i ogłaszali obecnym, zatem inskrypcje wyrzeźbione na zabytkach wznoszonych w miejscach publicznych, przypuszczalnie również odczytywano na głos podczas ceremonii lub 
procesji. Zdaniem Coggins (1992: 102), inskrypcja mogła niekiedy stanowić jedynie pewną niezbędną strukturę, która w ustach kapłana lub władcy byłaby przetwarzana w dwuwiersze i dodatkowo ozdabiana w zależności od ich własnej inspiracji i żarliwości. Posługiwanie się wyjątkowo bogatym językiem rytualnym było typowe nie tylko dla Majów, ale i dla innych kultur Mezoameryki.

\section{Pismo Majów na tle innych systemów pisma wezoameryce}

Po Mezopotamii, Dolinie Indusu, Egipcie i Chinach, Mezoameryka jest uważana za piątą na świecie kolebkę pisma. Majańskie glify nie były jednak jedynym systemem pisma w Mezoameryce. Początki pisma sięgają czasów Olmeków, lat 900-500 p.n.e., chociaż trudno w tym przypadku mówić o tradycji piśmienniczej, głównie z powodu braku tekstów. Na olmeckich naczyniach ceramicznych i na siekierkach wotywnych zachowały się symbole, które wywodziły się z ikonografii, wyrażały pewne idee typowe dla kultur Mezoameryki i spotykane później w innych systemach pisma. Na jednej z rzeźb z ośrodka La Venta, pochodzącej z około 650 r. p.n.e. widoczne są znaki przypominające wyglądem glify, które mogły określać imię przedstawionej osoby (Coe i Kerr, 1998: 63).

U Zapoteków, zamieszkujących ziemie obecnego stanu Oaxaca (Meksyk), pismo pojawiło się w latach 400-200 p.n.e. i jest uważane za logo-sylabiczne. Niestety uczonym nie udało się ustalić związku glifów z językiem zapoteckim, co uniemożliwia odczytanie inskrypcji, choć wiadomo, że część glifów oznacza daty, toponimy oraz przypuszczalnie imiona i tytuły osób (Oudijk, 2004: 32). Większość zapoteckich tekstów pochodzi z grobowców przedstawicieli elity, gdzie zostały namalowane na ścianach i sufitach bądź wyrzeźbione na odrzwiach, nadprożach i kamiennych płytach zapieczętowujących wejścia (Urcid, 2011: 125).

W późnym okresie preklasycznym, na ziemiach rozciągających się od południowego krańca stanu Veracruz po centralną część stanu Chiapas, pojawiło się logo-sylabiczne pismo epi-olmeckie, które odzwierciedla prawdopodobnie język będący wczesną wersja mixe-zoque (Kaufman i Justeson, 2001). Dysponujemy zaledwie dziewięcioma tekstami epi-olmeckimi, które zachowały się na zabytkach z Chiapa de Corzo, Tres Zapotes, Cerro de las Mesas i Tuxtli, a przede wszystkim na Steli z La Mojarra, gdzie wyjątkowo długa inskrypcja, obejmująca ponad 400 glifów, towarzyszy wizerunkowi władcy. W tekście, który opowiada o wydarzeniach z jego życia (objęciu władzy, odprawianych rytuałach i prowadzonych wojnach) wspominane są dwie daty: 143 r. n.e. i 150 r. n.e. Znaki glificzne spotykamy też w ośrodkach leżących na Wyżynach Gwatemali, w El Porton i Kaminaljuyu (z lat 400 p.n.e. -200 n.e.) oraz w południowej Gwatemali, w El Baul i Tak'alik Abaj (z lat 36 p.n.e. -126 n.e.). 
We wczesnym okresie klasycznym własny system pisma mieli również mieszkańcy Teotihuacan, gdzie glify zachowały się na malowidłach ściennych oraz na posadzce dziedzińca w dzielnicy La Ventilla (Taub, 2011: 77-109). W piśmie tym pojawiają się daty kalendarzowe, toponimy oraz imiona własne osób, choć trudno ustalić, w jakim języku zostały spisane i przez kogo mogły być odczytywane, tym bardziej że Teotihuacan było miastem kosmopolitycznym, zamieszkiwanym przez ludność posługującą się różnymi językami. Pod koniec okresu klasycznego podobne systemy pisma znajdujemy w Xochicalco (stan Morelos) i Cacaxtla (stan Tlaxcala), a w okresie postklasycznym w Tuli (stan Hidalgo).

Pismo Azteków, odzwierciedlające język nahuatl jest logo-sylabiczne, choć przewaga logogramów lub sylab jako znaków fonetycznych zależała od regionalnej tradycji piśmienniczej (Lacadena, 2008: 1-22). Przedstawiane za pomocą glifów słowa były często tworzone na zasadzie rebusu i ograniczały się do imion osób i bóstw, toponimów, dat oraz liczb, które podawały ilość najróżniejszych rzeczy, szczególnie w przypadku list danin. Uczonym nie udało się jednak odczytać wszystkich glifów.

Na uwagę zasługują również malowane rękopisy typowe dla tak zwanego stylu Mixteca-Puebla, który w okresie postklasycznym zaznaczył się na ziemiach centralnego i południowo-zachodniego Meksyku. Manuskrypty te zawierają jedynie glify dat, toponimów i imion, a poruszane $\mathrm{w}$ nich tematy dotyczące religii, mitologii, wydarzeń historycznych czy genealogii zostały przedstawione jedynie $\mathrm{w}$ formie scen. W rzeczywistości pismo mogło być inaczej postrzegane przez kultury Mezoameryki, tym bardziej że w wielu tamtejszych językach to samo słowo oznaczało zarówno pisanie, jak i malowanie: tz'ihb u Majów (Coe i Kerr, 1998: 89), tlacuilolli u Azteków i tacu u Misteków (Boone, 2000: 28). Biorąc pod uwagę ogromne znaczenie narracji ustnej, namalowane sceny, bez towarzyszącego im tekstu w konkretnym języku wystarczały do ich odpowiedniego zinterpretowania. Jak podkreśla Boone (2000: 32), malowane rękopisy w stylu Mixteca-Puebla mogły być odczytywane przez ludzi, którzy zamieszkiwali rozległy, wielojęzyczny i wielokulturowy region, a przedstawiciele tamtejszych elit rozumieli wspólne dla tego obszaru elementy ikonograficzne, szczególne sposoby przedstawiania postaci osób, bóstw czy wydarzeń takich, jak pielgrzymki, wojny, objęcie tronu bądź różne ceremonie religijne. W ten sposób manuskrypty piktograficzne były dostępne dla szerszego grona odbiorców.

\section{Wniosek}

Porównując pismo glificzne Majów z innymi, które rozwinęły się w Mezoameryce, wyraźnie widać, że nie miało sobie równych, choć pisma zapoteckie, epiolmeckie i azteckie były również logo-sylabiczne. Żadna inna kultura Mezoameryki 
nie pozostawiła po sobie tak ogromnej liczby tekstów i żadne inne pismo nie zostało odczytane w tak znacznej części. W inskrypcjach Majów mamy pełne zdania, ściśle ustaloną składnię, najróżniejsze formy czasownikowe, a zatem wszystko to, co pozwalało na tworzenie długich opowieści. Przede wszystkim natomiast posługiwano się nim przez niemal dwa tysiące lat.

\section{Bibliografia}

Boone, E.H. 2000. Stories in red and black. Pictorial histories of the Aztecs and Mixtecs. Austin: University of Texas Press.

Campbell, L. i T. Kaufman. 1985. "Mayan linguistics: where we are now?”. Annual Review of Anthropology 14. 187-98.

Coe, M.D. 1992. Breaking the Maya code. London and New York: Thames and Hudson.

Coe, M.D. i J. Kerr. 1998. The art of the Maya scribe. New York: Harry N. Abrams, Inc. Publishers.

Coggins, C. 1992. "Pure language and lapidary prose". W zbiorze: Danien, E.C. i R.J. Sharer (red.). New theories on the ancient Maya. Philadelphia: University of Pennsylvania Press. 99-108.

Grube, N. 2003. "Hieroglyphic inscriptions from Northwest Yucatan: an update of recent research". W zbiorze: Prem, H.J. (red.). Escondido en la selva. México: Universidad de Bonn - Instituto Nacional de Antropología e Historia. 339-371.

Houston, S., Robertson, J. i D. Stuart. 2000. "The language of classic Maya inscriptions". Current Anthropology 41 (3). 321-356.

Hull, K. 2003. Verbal art and performance in Ch'orti' and Maya hieroglyphic writing. Rozprawa doktorska. Austin: The University of Texas.

Josserand, K. 1991. "The narrative structure of hieroglyphic texts at Palenque”. W zbiorze: Field, V.M. (red.). Sixth Palenque round table 1986. University of Oklahoma Press: Norman. 12-31.

Kaufman, T. i J. Justeson. 2001. Epi-Olmec hieroglyphic writing and texts. Dokument elektroniczny: http://www.albany.edu/pdlma/EOTEXTS.pdf

Kettunen, H. i Ch. Helmke. 2011. Introduction to Maya hieroglyphs. (thumaczenie polskie: 2011. Wprowadzenie do hieroglifów Majów. tłum. Boguchwała Tuszyńska). Dokument elektroniczny: http://www. wayeb.com/download/resources/wh2011polish.pdf

Lacadena, A. 2008. "Regional scribal traditions: methodological implications for the decipherment of Nahuatl writing”. PARI Journal 8 (4). 1-22.

Lacadena, A. 2009. "Apuntes para un estudio de literatura maya antigua”. W zbiorze: Gunsenheimer, T., Harada, O. i J. Chuchiak. (red.). Text and context: Yucatec Maya literature in a diachronic perspective. Aachen: Ahaker Verlag. 31-52.

Lacadena, A. 2013. Basic grammar of hieroglyphic Maya. Handbook for advanced workshop, 18th European Maya Conference Wayeb. Bruksela. 5-68.

Lacadena, A i S. Wichmann. 2002. "The distribution of Lowland Maya languages in the classic period". W zbiorze: Tiesler, V., Cobos, R. i M. Greene Robertson (red.). La organización social entre los mayas, Memoria de la Tercera Mesa Redonda de Palenque. México: Conaculta-INAH. 275-319.

Lacadena, A. i K. Hull. 2012. Ancient Maya poetics. Handbook for advanced workshop, $17^{\text {th }}$ European Maya Conference Wayeb. Helsinki.

Oudijk, M.R. 2004. "La escritura zapoteca”. Arqueología Mexicana 12 (70). 32-35.

Saturno, W.A., Stuart, D. i B. Beltrán. 2006. "Early Maya writing at San Bartolo, Guatemala”. Science 311. 1281-1283. 
Schele, L. i M. Ayala. 1993. „De poesía e historia”. Vuelta 17 (203). 25-27.

Stuart, D. 2003. On the paired variants of TZ'AK. Dokument elektroniczny: http://www.mesoweb. com/stuart/notes/tzak.html

Taube, K. 2011. "Teotihuacan and the development of writing in early classic Central Mexico". W zbiorze: Boone, H.E. i G. Urton. (red.). Their way of writing. scripts, signs, and pictographies in Pre-Columbian America. Washington, D.C.: Dumbarton Oaks Research Library and Collection. 77-109.

Urcid, J. 2011. “The written surface as a cultural code". W zbiorze: Boone, H.E. i G. Urton (red.). Their way of writing. scripts, signs, and pictographies in Pre-Columbian America. Washington, D.C.: Dumbarton Oaks Research Library and Collection. 111-148. 